Krzysztof Kozłowski

\title{
CZYNNIKI RYZYKA W POLITYCE MIĘDZYNARODOWEJ WSPÓŁCZESNYCH CHIN
}

\section{Wprowadzenie}

Dyskusje na temat współczesnej sytuacji międzynarodowej Chińskiej Republiki Ludowej generalnie można podzielić na dwie grupy: o optymistycznym i pesymistycznym wydźwięku co do jej przyszłości. Wielu analityków spraw międzynarodowych twierdzi, że faktycznie już teraz należy ona do Państwa Środka. Mniej liczni, lecz wciąż obecni komentatorzy polityki międzynarodowej uważają, że ChRL jest kolosem na glinianych nogach, którego perspektywy są niepewne, za to przesadnie idealizowane. Pierwsi są zwykle pełni uznania zwłaszcza dla bieżącej wydajności chińskiego rozwoju gospodarczego. Drudzy mają szczególnie wiele wątpliwości co do efektywności chińskiego modelu politycznego w dłuższej perspektywie czasowej.

Obecnej siły Chin można upatrywać w wielu czynnikach. Jest poza dyskusją, że Chiny spełniają wymogi dotyczące terytorium i liczby ludności, by być określane mocarstwem - są czwartym terytorialnie państwem na świecie, a ich populacja obejmuje jedną szóstą ludności globu. ${ }^{1}$ Już same te fakty nie pozwalają innym mocarstwom na podejmowanie krytycznych decyzji w skali międzynarodowej bez wzięcia pod uwagę chińskich reakcji. Państwu Środka udało się również wykorzystać gospodarcze dobrodziejstwa globalizacji. Obecnie rynek chiński działa jak magnes na inwestorów zagranicznych. ${ }^{2}$ Siła militarna ChRL w wymiarze konwencjonalnym jest ogromna. Mimo dysproporcji technologicznej w konfrontacji z USA, na skalę regionalną Armia Ludowo-Wyzwoleńcza jest bardzo poważną siłą. Mniejszym niż amerykańskie możliwościom konwencjonalnym towarzyszy arsenał atomowy,

1 Niektórzy badacze wskazują jeszcze na pozytywne strony długiej linii brzegowej i geopolitycznej łatwości wchodzenia w interakcje wielostronne. Warto jednak zauważyć, że fakty te kiedyś przyczyniły się również do kolonizacji Państwa Środka. C.S. Gray, The Continued Primacy of Geography, „Orbis” 1996 $\mathrm{Nr} 40$, s. 258.

2 Punktem zwrotnym była Podróż na Południe (nanxun) D. Xiaopinga w 1992 roku, uważana za oficjalne błogosławieństwo dla liberalizacji gospodarczej w ChRL. Na marginesie, dopiero w marcu 2004 roku mocą poprawki do konstytucji ChRL wprowadzono zapis o ochronie własności prywatnej obywateli. A.J. Nathan, China’s Transition, Columbia University Press, New York 1997, s. 218. 
sukcesywnie rozbudowywany od 1964 roku. ${ }^{3}$ Chiny inwestują również w nowe technologie, o czym świadczy chociażby samodzielne wysłanie w kosmos pierwszego astronauty w sierpniu 2003 roku. ${ }^{4}$ Trudno też niedoceniać kompetencji politycznych obecnej linii kierownictwa Komunistycznej Partii Chin. Mimo ruchów odśrodkowych w Xinjiang i Tybecie oraz wróżenia Chinom losów ZSRR, Państwo Środka rozwija się $\mathrm{z}$ według własnej strategii. $\mathrm{W}$ tym kontekście na uwagę zasługuje zwłaszcza umiejętność manewrowania między interesami innych mocarstw, stosunkowo bezkonfliktowe promowanie własnych interesów oraz płynne, pozbawione większych wstrząsów przekazywanie władzy od 1990 roku. ${ }^{5}$

Obecnie ChRL dysponuje ogromnym potencjałem politycznym i gospodarczym. Trzeba jednak przyznać, że w przyszłości stanie przed koniecznością rozwiązania licznych problemów mogących ten potencjał drastycznie ograniczyć, co nie pozostanie bez wpływu na efektywność jej polityki zagranicznej. Bez względu na podziw lub obawy, sympatie lub niechęć żywione wobec Chin warto w związku z tym na chwilę odejść od analiz bieżącej sytuacji międzynarodowej ChRL, by zdefiniować główne zagrożenia dla przyszłego tempa ich przemian. O ile bowiem można powiedzieć, że Państwo Środka umiejętnie wykorzystało sprzyjające mu okoliczności polityczno-gospodarcze na przełomie XX i XXI wieku, o tyle z jego jutrem wiąże się wiele znaków zapytania. Celem opracowania nie jest przy tym pesymistyczna krytyka chińskiej trajektorii rozwoju politycznego i gospodarczego czy optymistyczne ekstrapolacje ich obecnych sukcesów w przyszłość. Jest nim natomiast zdefiniowanie zmiennych istotnych w formułowaniu prognoz odnośnie do polityki międzynarodowej współczesnych Chin. Spojrzenie na przyszłość ChRL umożliwia bowiem formułowanie pytań, które, choć w większości na chwilę obecną pozostają bez pełnej odpowiedzi, powinny być brane pod rozwagę w budowaniu agend politycznych innych mocarstw. Są one tym bardziej istotne, że zbyt wiele współczesnych opracowań na temat chińskiej polityki zagranicznej mówi więcej o przekonaniach ich autorów co do jej porażek lub sukcesów niż co do czynników mogących na nią mieć jakikolwiek realny wpływ.

${ }^{3}$ D. Shambaugh, Modernizing China's Military: Progress, Problems and Prospects, University of California Press, Berkeley, London 2002, s. 70-72.

${ }^{4}$ Kolejne jest planowane w 2012 roku. Więcej zob.: J.W. Lewis, X. Litai, China Builds the Bomb, Stanford University Press, Stanford 1988.

5 J. Mearshimer, The Tragedy of Great Power Politics, W.W. Norton and Co., New York 2001, s. 30-36. 


\section{Czynniki ryzyka}

Powodzenie Chin w realizacji prowadzonej współcześnie polityki międzynarodowej zależy od umiejętności sprostania przez chiński reżim kilku wyzwaniom rysującym się przed Państwem Środka na przełomie pierwszej i drugiej dekady XXI wieku. Wypływają one zarówno z czynników międzynarodowych, jak i wewnętrznych. Umiejętność stawienia im czoła może być podstawą oceny nie tylko skuteczności chińskiej polityki zagranicznej, ale również prognozowania ewentualnych jej przeobrażeń.

Pierwsze wyzwanie, jakiemu musi sprostać chińska polityka zagraniczna, jest nierozerwalnie związane $\mathrm{z}$ głęboką i gwałtowną transformacją społeczną, gospodarczą i polityczną, jaką przechodzi Państwo Środka. Wpływ dynamiki przemian wewnętrznych ma kluczowe znaczenie dla jego zachowań międzynarodowych. Jednocześnie skala zachodzących zmian rodzi pytanie o zdolności adaptacyjne polityki zagranicznej do wymogów polityki wewnętrznej Chin. Nierozstrzygnięta pozostaje bowiem kwestia stopnia koordynacji pomiędzy polityką wewnętrzną a polityką zagraniczną, która po kilku dekadach relatywnie małej aktywności międzynarodowej na przestrzeni ostatnich kilkunastu lat nabrała niespotykanego rozmachu. Już obecnie problemem Chin jest nie zawsze zadowalająca koordynacja decyzji wewnętrznych, stanowiących podstawę polityki zagranicznej. ${ }^{6}$ Powstaje pytanie, czy chińskie władze, niejako na bieżąco ucząc się zasad aktywności międzynarodowej w kontekście dynamicznie zmieniającego się otoczenia międzynarodowego, opracowały mechanizmy koordynacyjne w bardzo złożonej strukturze współzależności decyzyjnej między swoimi wieloma instytucjami wewnętrznymi? Na ile podatny na takie zakłócenia pozostanie proces podejmowania decyzji w sprawach polityki zagranicznej?

Historia Chin pokazuje, że do zmian politycznych, a zwłaszcza zmian elit rządzących w Państwie Środka tradycyjnie dochodziło w drodze obalenia sprawującego władzę reżimu. Chiny po objęciu władzy przez Deng Xiaopinga są pierwszym w historii przykładem tak poważnej zmiany kursu politycznego bez wstrząsów wewnętrznych na większą, ogólnokrajową skalę. W kontekście polityki zagranicznej takim wstrząsem były jednak demonstracje na placu Tiananmen. O ile polityczna burza na arenie wewnętrznej państwa ucichła relatywnie szybko, na arenie międzynarodowej

${ }^{6}$ Najlepszym przykładem ich braków było chińskie zarządzanie epidemią SARS w 2002 roku. Więcej patrz: M. Lanteigne, China and International Institutions: Alternate Paths to Global Power, Routledge, London-New York 2005, s. 27-28. 
ChRL znacznie dłużej musiała radzić sobie z komplikacjami w stosunkach ze światem zachodnim. Powstaje więc pytanie, na ile umiejętność przeprowadzania zmian wewnętrznych idzie w parze $\mathrm{z}$ umiejętnością bezkonfliktowego wplatania ich w realia polityki globalnej. Rosnąca złożoność okoliczności zewnętrznych i wewnętrznych, kształtujących sytuację ChRL, znacząco utrudnia dokonanie kalkulacji kosztów i zysków poszczególnych działań podejmowanych na tym polu. ${ }^{7}$ Krajobraz interakcji między czynnikami wewnętrznymi i kierunkami rozwoju polityki zagranicznej w miarę dopuszczania do dyskusji czynników pozarządowych będzie ulegał coraz większemu skomplikowaniu. ${ }^{8}$ Trend ten będzie się prawdopodobnie wzmacniał, ale raczej nie w wyniku demokratyzacji systemu, lecz chęci utrzymania i wzmocnienia legitymizacji przez Partię Komunistyczną. Deideologizacja chińskiego systemu państwowego zmusza aparat partyjny do otwierania się na kolejne grupy interesu.

Nie bez znaczenia pozostaje również znane już z przeszłości wykorzystywanie nastrojów społecznych przez zwalczające się frakcje w KPCh do rozgrywek wewnętrznych o władzę. ${ }^{9} \mathrm{~W}$ drugim dziesięcioleciu XXI można się zwłaszcza spodziewać coraz częstszych rozłamów i narastania różnic pomiędzy grupami politycznymi żywiącymi sentymenty względem czasów Mao Tse Tunga a elitami technokratycznymi, związanymi z obecnym kierownictwem KPCh. Nie wolno również zapominać o rosnącym w siłę chińskim nacjonalizmie. Chociaż politycy chińscy wykorzystywali motywy nacjonalistyczne do kierowania sprawami wewnętrznymi państwa, w dłuższej perspektywie i w kontekście rosnącego wpływu różnych grup interesów na proces decyzyjny może on zacząć ograniczać swobodę wyborów w polityce międzynarodowej ChRL. Pod koniec pierwszej dekady XXI wieku uwidocznił się np. silny resentyment wobec Japonii, mogący znacząco komplikować stosunki $\mathrm{z}$ ważnym gospodarczo sąsiadem. ${ }^{10} \mathrm{~W}$ sytuacjach konfliktowych może mieć to dodatkowy, negatywny wpływ na rozwój wydarzeń. Kierownictwo chińskie wyraźnie zdaje sobie sprawę z sytuacji i zaczyna przykładać coraz większą wagę do zarządzania odbiorem społecznym podejmowanych centralnie decyzji politycznych i gospodarczych. Analizy polityki zagranicznej Chin nie mogą więc opierać się na bezrefleksyjnym założeniu o stabilności wewnętrznej Państwa Środka.

7 E. Downs, Business Interest Groups in Chinese Politics: The Case of Oil Companies, w: C. Li, China's Changing Political Landscape: Prospects for Democracy, Brookings Institution Press, Washington 2008, s. $121-141$.

8 Ibidem.

9 J. Fewsmith, Elite Politics in Contemporary China, M.E. Sharpe, Armonk 2001.

10 Adhere to Peaceful Development Road, Push Forward Building of Harmonious World, „People's Daily” 24.08.2006. 
W powyższym kontekście źródłem poważnego niepokoju pozostaje również niewydolność chińskiej administracji. ${ }^{11}$ Systemowa wręcz korupcja, rosnące napięcia między peryferiami a centrum, słaby nadzór ekologiczny i zdrowotny, braki systemu ochrony zdrowia czy rosnący nacjonalizm mogą być poważnymi wyzwaniami dla rozwijającej się chińskiej gospodarki oraz biurokracji państwowo-partyjnej. ${ }^{12}$ Zagadnieniem wymagającym uwagi jest również system zarządzania kryzysowego w Chinach. Biurokracja chińska w kwestiach bezpieczeństwa napotyka poważny problem pod postacią przerostu procedur tajnych, złożoności podziałów procedur na wojskowe, cywilne czy wywiadowcze oraz braku koordynacji między poszczególnymi służbami. Brak przejrzystości w tym zakresie może rodzić obawy sąsiadów i obserwatorów, a także pytania o prawdziwe ambicje ChRL. ${ }^{13}$ Są to słabości, które mogą ujawnić się w chwilach kryzysów międzynarodowych lub rozprzestrzenić na sąsiednie państwa, stając się regionalnym problemem i przeszkodą w bieżących relacjach. Najlepszym przykładem była nie tylko powolna i nieskoordynowana reakcja władz chińskich na zagrożenie SARS, ale również wynikające z niej zagrożenia dla państw z nim sąsiadujących. W 2005 roku podobny kryzys miał miejsce w kwestii zanieczyszczenia rzeki Songhua - mającej ujście w Federacji Rosyjskiej. ${ }^{14}$ Mało rozwinięta kontrola publiczna nad niektórymi szybko rozwijającymi się sektorami państwa w połączeniu z nieefektywnością już istniejących mechanizmów kontrolnych mogą stać się czynnikiem bardzo niekorzystnym dla rozwoju polityki międzynarodowej Państwa Środka w przyszłości.

Kolejną poważną wątpliwość odnośnie do polityki chińskiej na arenie międzynarodowej wzbudza założenie, że Państwo Środka zrezygnowało z ekspansji wojskowej na rzecz gospodarczej. Chiny są pierwszym współczesnym przykładem mocarstwa, które zbudowało swój status bez używania siły militarnej na większą skalę na zewnątrz własnych granic. Potencjalne problemy związane z sukcesją władzy powodują jednak również, że jedną z najpoważniejszych wątpliwości w ocenach międzynarodowych Państwa Środka pozostają jego pokojowe intencje. Często znajdują się one w sprzeczności z bardzo dużym naciskiem kładzionym na ochronę informacji dotyczących jego potencjału wojskowego, jak również z szybkim rozrostem Armii Ludowo-Wyzwoleńczej. ${ }^{15}$ Czynnikiem komplikującym sytuację międzynarodową

\footnotetext{
11 S.L. Shirk, China: Fragile Superpower, Oxford University Press, Oxford 2007.

12 N.R. Lardy, China and the Asian Contagion, „Foreign Affairs” 1998 Vol. 77(4), s. 78-88.

${ }^{13}$ Należy jednak zwrócić uwagę, że np. w ćwiczeniach wojskowych coraz częściej biorą udział obserwatorzy z zewnątrz.

${ }^{14}$ China to handle Songhua River pollution with responsible attitude, „People’s Daily” 09.12.2005, http:// english.peopledaily.com.cn/200512/09/eng20051209_226724.html (dostęp 12.03.2010).

15 B. Gill, M. Green, K. Tsuji, W. Watts, Strategic Views on Asian Regionalism: Survey Results and Analysis, Center for Strategic and International Studies, Washington 2009, s. 4-8.
} 
ChRL są jej relacje $\mathrm{z}$ Tajwanem, poniekąd również stanowisko $\mathrm{w}$ sprawie Tybetu i Xinjiang. Czasami wręcz agresywne reakcje polityczne wobec innych państw na płaszczyźnie tych trzech obszarów stawiają deklarowane pokojowe nastawienie Chin pod znakiem zapytania. Mimo że postawa Chin nie jest już tak nieprzejednana jak kiedyś, na przestrzeni pierwszej dekady XXI wieku można podać kilka przykładów przeczących pokojowym intencjom Państwa Środka: zamrożenie kontaktów z Singapurem w latach 2004-2006 z powodu wizyty jego premiera na Tajwanie; domaganie się od Australii w 2005 roku deklaracji niezaangażowania w potencjalny konflikt sino-tajwański, mimo wiążącego ją ze Stanami Zjednoczonymi sojuszu wojskowego; przegłosowanie ustawy anty-secesyjnej w 2005 roku, która znacząco pogorszyła wizerunek Chin w Europie i poskutkowała przedłużeniem ograniczenia handlu bronią z Państwem Środka; publiczne zajmowanie stanowiska w 2006 roku przez ambasadora Chin w Korei Południowej i doradzanie miejscowym władzom ograniczenia obecności amerykańskiej w tym kraju wyłącznie do jego obrony oraz zadbanie o jego niezaangażowanie $\mathrm{w}$ przypadku konfliktów regionalnych np. potencjalnym tajwańskim, co zostało odebrane jako wtrącanie się w sprawy wewnętrzne tego kraju i wywołało nawet publiczne dyskusje o zmniejszeniu zależności gospodarczej Republiki Korei od Chin. ${ }^{16}$ Zaostrzenie się sytuacji na Morzu Południowochińskim czy kwestia ograniczenia wydobycia ziem rzadkich, mające miejsce na przełomie lat 2010 i 2011, również rodzą w tym zakresie wiele obaw.

W powyższym kontekście rodzi się również niepokój o przyszłe losy chińskiej polityki gospodarczej. W wielu ocenach chińska ekspansja ekonomiczna miała przecież zastąpić militarną. Czy Chiny będą jednak w stanie konsekwentnie kontynuować obecną politykę gospodarczą? Nawet pobieżny rzut oka na historię gospodarczą drugiej połowy XX wieku pozwala stwierdzić, że najpoważniejsze konsekwencje miały kryzysy i załamania finansowe w systemach, w których władza publiczna jest słabo lub praktycznie w ogóle nieograniczona, a wolny rynek i własność prywatna mało obecne. W kontekście Chin i ich sukcesu gospodarczego polityki reform i otwarcia ostatnich trzydziestu dwóch lat, kiedy to przebudowywano Chińską Republikę Ludową zgodnie z modelem ,jedno państwo dwa systemy”, warto pamiętać, że Chiny wciąż są przykładem systemu silnie scentralizowanego i etatystycznego. ${ }^{17}$

${ }^{16}$ E.S. Medeiros, K. Crane, E. Heiginbotham, N.D. Levin, J.F. Lowell, A. Rabasa, S. Seong, Pacific Currents: The Responses of U.S. Allies and Security Partners in East Asia to China's Rise, RAND, Santa Monica 2008, s. 70-71.

$17 \mathrm{Na}$ marginesie trzeba jednak zaznaczyć, że potencjalne wątpliwości dotyczące funkcjonowania dwóch, zdawałoby się mało kompatybilnych, systemów w jednym państwie nie są w pełni uzasadnione. Patrząc na rozwiązania demokratyczne czy szerzej polityczne obecne w innych mocarstwach światowych, trudno stwierdzić, czy mamy do czynienia $\mathrm{z}$ jakimkolwiek uniwersalnym modelem współistnienia gospodarki wolnorynkowej z jakimkolwiek systemem politycznym. Jako przykład może posłużyć odmienne 
Władza publiczna ma w nim do tej pory nikłe instytucjonalne ograniczenia. Władza polityczna, mimo że dwie trzecie chińskiego PKB wytwarzają już prywatni przedsiębiorcy, wciąż pozostaje tożsama z władzą gospodarczą. Ograniczenie kręgu decydentów do osób reprezentujących to samo przygotowanie zawodowe i polityczne, jak ma to miejsce w Chinach, nie sprzyja rozpatrzeniu wszelkich możliwych opcji działania, zarówno w przypadku kryzysu gospodarczego, jak i międzynarodowego. Komunistyczna Partia Chin nie uległa magicznemu przeobrażeniu w 1978 roku. Wręcz przeciwnie, reformy Deng Xiaopinga były do końca lat osiemdziesiątych ograniczone brakami kadrowymi (Wielki Skok i ,rewolucja kulturalna” zebrały krwawe żniwo wśród chińskiej inteligencji) oraz sporami wewnątrz partii, które pochłonęły pierwsze lata urzędowania pierwszego sekretarza. ${ }^{18}$

Polityka reform i otwarcia, zapoczątkowana przez Deng Xiaopinga, związana była z przejęciem steru władzy przez pragmatycznie myślących partyjnych technokratów zorientowanych na troskę o ekonomię przy zachowaniu monopolu władzy partii. Jednakże nie było tak zawsze. Historycznie to właśnie Chiny były areną dwóch spośród najbardziej brutalnych i drastycznych eksperymentów społeczno-gospodarczych XX wieku: Wielkiego Skoku i „rewolucji kulturalnej”. Pod kątem konsekwencji mogą one być porównywane jedynie do katastrofy humanitarno-gospodarczej pokroju stalinowskiej kolektywizacji rolnictwa na początku lat trzydziestych w ZSRR. Piewcy chińskiego cudu gospodarczego mogą oczywiście ripostować, że dzisiejsze Chiny nie są już tak bardzo narażone na rządy wodzowskie w stylu Mao. Należy jednak również pamiętać o mniej drastycznych, ale gospodarczo dotkliwych przypadkach poważnych błędów ekonomicznych w państwach socjalistycznych, których korekta w sytuacji jedności władzy politycznej i gospodarczej była praktycznie niemożliwa. W przypadku współczesnych Chin problemem może okazać się mała cyrkulacja elit, co naraża władze na poleganie na określonej perspektywie politycznej i niedostrzeganiu zagrożeń. Przy centralnym kierowaniu powstaje ryzyko popełnienia błędu, którego nie ma kto skorygować. Wystarczy tu wymienić: forsowanie uprawy kukurydzy

amerykańskie i europejskie zapatrywanie na demokrację. W przypadku Chin nie można więc oczekiwać powielania jakiegokolwiek modelu polityczno-gospodarczego. Jak wielokrotnie zauważa Bogdan Góralczyk, ChRL jest w tym względzie unikalnym modelem nieodwołującym się do standardów zewnętrznych. Więcej: B. Góralczyk, Chiński feniks: paradoksy wschodzącego mocarstwa, Wydawnictwo Sprawy Polityczne, Warszawa 2010.

18 Briefing, China's reforms. The second Long March, „The Economist” 13.12.2008, s. 30. Warto zauważyć, że właśnie w wąskim charakterze kręgu decyzyjnego KPCh w zestawieniu z bardziej demokratycznym podejściem do gospodarki rządu np. Indii ekonomiści upatrują w przyszłości głównego źródła szybszego i bardziej efektywnego rozwoju Delhi niż Pekinu. Więcej patrz: Briefing, business in India. A bumpier but freer road, ,The Economist” 2.10.2010, s. 68. 
przez Chruszczowa w ZSRR, trzciny cukrowej na Kubie przez Fidela Castro czy wpędzenie Polski w pułapkę długu zagranicznego za czasów Edwarda Gierka. ${ }^{19}$

Historia XX wieku pokazuje, że władza polityczna zbyt mocno powiązana z władzą ekonomiczną na dłuższą metę szkodzi gospodarce. Mowa nie tylko o ryzyku załamań ekonomicznych, co stanowi przedmiot odrębnych debat ekonomistów i polityków. ${ }^{20}$ Bezsprzecznym faktem pozostaje, że pierwszymi ofiarami w takiej sytuacji są wolna konkurencja oraz innowacyjność gospodarcza - zręby gospodarki wolnorynkowej, którą chińskie władze od ponad ćwierć wieku starają się przeszczepić na rodzimy grunt. Nie jest to zresztą zarzut wyłącznie pod adresem gospodarek socjalistycznych - przykładowo poważna część kryzysów finansowych w państwach OECD jest związana z polityką fiskalną państwa (jak chociażby rozdymanie do granic możliwości długu publicznego, czego przykładem jest współczesna Grecja). Nie wolno również zapominać, jak czasem poważne problemy wynikają nawet $\mathrm{w}$ państwach o gospodarkach wolnorynkowych w związku z utrzymywaniem przewagi własności państwowej w niektórych ich sektorach. Przykładem są chociażby upolitycznione bankowe decyzje parainwestycyjne, np. dotyczące przyznawania kredytów hipotecznych przez Fannie Mae i Freddie Mac.

W kontekście Chin warto zauważyć, że większość wymienionych wyżej problemów jest w świadomości przeciętnego obywatela zapisywana na konto wolnego rynku. Tymczasem mają one źródła również $\mathrm{w}$ działaniach i zaniechaniach władz publicznych, odgrywających w omawianym zakresie często rolę ostatecznego dysponenta decyzji gospodarczych. W sytuacji systemów politycznych, w których proces decyzyjny ma wciąż w dużej mierze charakter, używając nomenklatury analizy systemowej D. Eastona, czarnej skrzynki ${ }^{21}$ - tzn. pozostaje poza kontrolą społeczną w rękach aparatu partyjnego, decydentów znacznie łatwiej propagandowo cenić za zasługi niż obarczać odpowiedzialnością za negatywne konsekwencje ich własnych działań, które można przerzucić np. na globalne załamanie gospodarcze. Jednocześnie trudniej na czas dostrzec niebezpieczeństwa ukryte w ich decyzjach i im zapobiegać. Warto zwrócić uwagę, że wbrew antykapitalistycznej retoryce głównymi przyczynami załamań finansowych nieodmiennie są kombinacje nieefektywnych,

19 L. Balcerowicz, Kryzys finansowy czy kryzys myślenia?, wykład wygłoszony na Konferencji PKN Orlen 21.10.2010, przedruk, http://www.rp.pl/artykul/9211,538562-Kryzys-finansowy-czy-kryzys-myslenia-.html (dostęp 10.10.2010).

20 Jako przykłady mogą posłużyć: akademicki spór o słuszność interwencjonizmu państwowego między szkołami keynesowską i chicagowską czy spór między polityką gospodarczą zapoczątkowaną w Wielkiej Brytanii przez M. Thatcher oraz w USA przez R. Reagana a powstałą w opozycji doń doktryną trzeciej drogi Nowej Partii Pracy T. Blaira czy nowej linii politycznej niemieckiej socjaldemokracji G. Schroedera.

21 Więcej o analizie systemowej w politologii i ekonomii politycznej zob.: D. Easton, The Analysis of Political Structure, Routledge, New York 1990. 
a czasem wręcz błędnych interwencji publicznych. Wolny rynek nie jest tak stabilny, jak chciałoby tego wielu neoliberałów. Sam z siebie nie produkuje jednak również potężnych kryzysów ani wielkich boomów. ${ }^{22} \mathrm{~W}$ obu przypadkach bliższe spojrzenie pozwala dostrzec, często niedostrzegalną dla szerszego audytorium, aktywność władzy publicznej. ${ }^{23}$ Należy pamiętać, że w przyszłości w Chinach nadal nie znajdziemy dla niej żadnych hamulców. Warto przy tym zauważyć, że o ile dotychczasowi decydenci w Pekinie byli skuteczni w swoich działaniach, tempo reform wewnętrznych uległo w ciągu ostatnich kilku lat spowolnieniu pod zarzutami części aktywu partyjnego o zbyt dalekie odchodzenie od ideałów socjalizmu. Ekonomiczny pragmatyzm Komunistycznej Partii Chin nie musi więc być wcale przesądzony. ${ }^{24}$

Rynki wolne od nadmiernej regulacji i możliwie elastyczne pozostają głównymi mechanizmami innowacyjności oraz niwelowania wewnętrznych i zewnętrznych skutków recesji czy wstrząsów gospodarczych. Prezentowane tu tezy nie mają służyć pochwale zachodniego modelu demokracji wolnorynkowej. Jest on pełen mniej i bardziej ukrytych wad. W kontekście analizy wyzwań, jakie stoją w przyszłości przed ChRL, uznanie dla jej modelu gospodarczo-politycznego nie powinno jednak przysłaniać uniwersalnych dla każdej gospodarki ograniczeń, wpisanych również w mechanizmy ekonomiczne Państwa Środka. Warto również zauważyć, że chiński sukces $\mathrm{w}$ radzeniu sobie $\mathrm{z}$ kryzysami finansowymi na przestrzeni ostatniego ćwierćwiecza jest wynikiem nie tylko skuteczności działań tamtejszych rządów, ale również funkcją bardzo pesymistycznej oceny stanu gospodarczego świata zachodniego. Sukcesy Państwa Środka są po części mierzone jego obiektywną efektywnością, a po części subiektywnym wrażeniem ostatnich porażek finansowo-gospodarczych świata zachodniego, co niekiedy może skłaniać do przesadnego optymizmu w ocenach przyszłości gospodarczej Chin. ${ }^{25}$

22 P. Ball, Masa krytyczna, Amber, Kraków 2007, s. 243.

23 R. Gordon, Czy socjaldemokraci doprowadzili do kryzysu hipotecznego?, w: Kryzys. Przewodnik Krytyki Politycznej, Warszawa 2009, s. 213 i nast.

${ }^{24}$ Ekonomiści są zgodni, że przewaga własności prywatnej nad własnością państwową (socjalizm) czy polityczno-prywatną (autorytaryzm) jest w dłuższej perspektywie bardziej produktywna z punktu widzenia długofalowego rozwoju państwa. Dotyczy to również banków. Fakt, że chińskie banki oparły się kryzysowi 2008 roku nie zmienia ich bardzo niekorzystnej sytuacji wywołanej ogromnymi wierzytelnościami sektora publicznego i wciąż niedużymi rozmiarami rynku wewnętrznego. Dominacja własności państwowej lub polityczno-prywatnej w dłuższej perspektywie grozi stagnacją i podnosi ryzyko błędów planistycznych. Konkurencja wolnorynkowa zdaje się być niezastąpionym mechanizmem innowacyjności i efektywności gospodarczej, zwłaszcza w sektorze instytucji bankowych. Więcej zob.: Briefing, China’s reforms..., op.cit., s. 31 .

${ }^{25}$ W tym kontekście należy zwłaszcza zwrócić uwagę na nieuniknione spowolnienie rozwoju gospodarki chińskiej nastawionej w dużej mierze na eksport do państw cywilizacji zachodniej, przeżywających obecnie kolejną falę kryzysu i niebędących już tak atrakcyjnymi rynkowo jak jeszcze przed dekadą. 
W analizie międzynarodowej efektywności gospodarczej ChRL nie należy tracić z oczu jej uwarunkowań wewnętrznych. W tle stojących przed Chinami wyzwań gospodarczych coraz bardziej widoczne stają się wyzwania demograficzne. Kolejne pytanie o przyszłość Chin w związku z tym brzmi: Czy Państwo Środka ma wystarczająco dużo ludzi, by utrzymać dotychczasowe tempo wzrostu? Lub bardziej precyzyjnie: Czy ChRL zdąży się wystarczająco wzbogacić, zanim zacznie ponosić koszty gwałtownie starzejącego się społeczeństwa?

Chiny stoją obecnie wobec ryzyka negatywnych konsekwencji zmian demograficznych spowodowanych spadkiem przyrostu naturalnego i rosnącą populacją osób $\mathrm{w}$ wieku poprodukcyjnym. W perspektywie najbliższych dwudziestu lat ChRL będzie zmuszona do rozwiązania coraz bardziej palących kwestii powszechnych ubezpieczeń społecznych i opieki zdrowotnej, które w obecnym kształcie wydatnie ograniczają rozmiary rynku wewnętrznego. $\mathrm{O}$ ile Chiny przez ostatnich dwadzieścia lat mogły się cieszyć relatywnie korzystnymi proporcjami liczby osób starszych i dzieci do liczby osób pracujących, obecnie liczba osób w wieku poprodukcyjnym zaczyna gwałtownie rosnąć. Starzejąca się populacja bez zabezpieczeń socjalnych będzie generować rosnący popyt na nowe usługi z zakresu ochrony zdrowia i przejmować rosnącą część zasobów na jego pokrycie. Na podstawie dostępnych danych trudno stwierdzić, czy Chiny przedsięwzięły jakiekolwiek kroki w tym względzie. Do tej pory w Państwie Srodka kwestiami z tego zakresu zajmowały się tamtejsze ze wszech miar rozbudowane przedsiębiorstwa państwowe, obecnie w przeważającej liczbie rozwiązane. $\mathrm{W}$ ich miejsce nie wprowadzono jednak na razie żadnego nowego systemu.

Szansa Chin leży w scentralizowanym systemie decyzyjnym, co daje im teoretycznie łatwość implementacji potrzebnych decyzji socjoekonomicznych. Bez wątpienia wciąż potężna władza centralna daje Chinom siłę do realizacji programów politycznych umożliwiających wykorzystanie potencjału ludnościowego państwa. Silne państwo ułatwia realizowanie trudnych decyzji politycznych. W wyniku przerostu procedur tajnych w Państwie Środka często jednak niełatwo realistycznie oceniać jego możliwości działania. Wystarczy wspomnieć, że najprawdopodobniej przyszły przewodniczący ChRL, Xi Jinping, w ramach kariery w administracji prowincji Shaanxi, Hebei, Fujian i Zhejiang musiał wprowadzić system weryfikacji oficjalnych danych o stanie lokalnej gospodarki. ${ }^{26}$

Poważnym problemem w toku zmian polityki demograficznej może się okazać brak jasnych wskazówek co do natury podejmowanych działań. Przeszkodą może być także system instytucji powołanych do wprowadzania w życie polityki jednego

${ }^{26}$ China's succession: The next Emperor, „,The Economist”, http://www.economist.com/node/17308123 (dostęp 23.06.2011). 
dziecka. Jego demontaż uderza bowiem w interesy dużej grupy biurokratycznej związanej blisko z władzą i będącej w pewnym sensie jej emanacją. O ile ChRL zdawała się być bardzo skuteczna w realizacji polityki antynatalistycznej, o tyle odwrócenie trendu może być znacznie bardziej skomplikowane. Wynika to nie tylko z obiektywnych zmian tkanki społecznej (np. wzrostu aspiracji kobiet i odchodzenia przez nie od ról społecznych związanych głównie z macierzyństwem) oraz konieczności podjęcia zupełnie nowego, przeciwnego do dotychczasowego typu aktywności ze strony państwa, ale również z faktu, że cele polityki pronatalistycznej są znacznie trudniejsze do osiągnięcia. Na przestrzeni ostatnich lat zarówno demokratyczne, jak i autokratyczne reżimy w Europie odkryły, że polityka pronatalistyczna wpływa raczej na czas podjęcia decyzji o posiadaniu dzieci niż na ich liczbę. ${ }^{27}$ Poza tym, nawet zakładając jej sukces, na efekty w postaci zwiększonej liczby obywateli wchodzących w wiek produkcyjny trzeba będzie czekać około dwóch dekad. Jednocześnie jej sukces oznaczałby, że przez okres dorastania nowych, liczniejszych pokoleń państwo będzie musiało sobie radzić ze wzrostem liczby dzieci pozostających na utrzymaniu relatywnie nielicznej grupy rodziców, którzy już będą ponosić koszty starzenia się społeczeństwa.

Analizując czynniki ryzyka w rozwoju polityki międzynarodowej Chin, nie powinno się poprzestawać na refleksji nad zagadnieniami obiektywnymi - jak ich siła gospodarcza czy militarna. Nie mniej ważne są problemy związane z wizerunkiem Państwa Środka na arenie międzynarodowej. W tym kontekście istotnym wyzwaniem dla chińskiej polityki zagranicznej będzie sprostanie oczekiwaniom i wyobrażeniom ze strony innych państw. Jeszcze w latach dziewięćdziesiątych Państwo Środka mogło korzystać z niskich oczekiwań pod własnym adresem ze strony otoczenia międzynarodowego. Przykładem może być bardzo pozytywna reakcja na pomoc finansową, mimo że relatywnie nie imponującą, wystosowaną przez Chiny w 1997 roku pod adresem państw azjatyckich. Jak dalece sytuacja uległa zmianie, pokazuje krytyka polityki Chin w Sudanie przy okazji olimpiady letniej w 2008 roku w Pekinie i rosnące naciski o niepozostawanie obojętnym wobec sytuacji społeczno-politycznej w państwach afrykańskich, w których są coraz bardziej zaangażowane ekonomicznie. Na początku drugiej dekady XXI wieku oczekiwania odgrywania przez Chiny bardziej twórczej niż dotychczas roli w regionie Azji i Pacyfiku były

27 G. Hugo, Declining Fertility and Policy Intervention in Europe: Some Lessons for Australia?, ,Journal of Population Research" 2000 Vol. 17, Nr 2; D.P. Henry, Eastern Europe: Pronatalist Policies and Private Behaviour, „Population Bulletin” 1982 Vol. 36, Nr 6, s. 1-49; J. Grant, J.S. Hoorens, S. Sividasan, M. van het Loo, J. DaVanzo, L. Hale, S. Gibson, W. Butz, Low Fertility and Population Ageing: Causes, Consequences and Policy Options, MG-206-EC, RAND, Santa Monica 2004, http://www.rand.org/pubs/monographs/MG206/ (dostęp 23.06.2011). 
już formułowane ze strony Australii i państw Oceanii. ${ }^{28}$ ChRL musi się więc zacząć liczyć z faktem, że wraz ze wzrostem własnego potencjału gospodarczego i politycznego wzrastać będą również oczekiwania odnośnie do większego zaangażowania w sprawy międzynarodowe oraz brania na siebie większej odpowiedzialności za jej kształt w przyszłości.

W powyższym kontekście wielu obserwatorów ma wątpliwości, czy Chiny $\mathrm{w}$ ogóle będą chciały brać na siebie dodatkowe ciężary związane $\mathrm{z}$ ich pozycją międzynarodową. ${ }^{29}$ Od ponad ćwierć wieku prowadząc współpracę gospodarczą z państwami rozwijającymi się, ograniczały własne zaangażowanie polityczne do minimum presji związanej z osłabianiem pozycji Tajwanu i wykluczaniem współpracy z ewentualnymi ruchami separatystycznymi na terytorium chińskim. Nie należy też pomijać faktu, że bezpieczeństwo jako „dobro publiczne” w systemie międzynarodowym może wymagać nakładów, których ChRL na obecnym etapie rozwoju gospodarczego nie będzie chciała podjąć. Nastrajającymi optymistycznie sygnałami są z pewnością rosnące zaangażowanie humanitarne ChRL, czy, w pewnym zakresie, operacja antypiracka w zatoce adeńskiej w 2008 roku. ${ }^{30}$ Jednocześnie np. polityka przedsiębiorstw chińskich w Afryce pozostawia wiele do życzenia i ulega zmianom praktyczne wyłącznie pod wpływem nacisków zewnętrznych. Pojawiają się też znaki zapytania, na ile Chiny są w praktyce wiarygodnym partnerem politycznym. Jeśli sieć zagranicznych powiązań chińskich rośnie, to wiele z nich nie zostało jeszcze poddanych jakiejkolwiek próbie. ${ }^{31}$ Część nie wydaje się też już tak silna jak jeszcze niespełna dekadę temu. Na przykład na przełomie lat 2010 i 2011 pojawiły się napięcia we współpracy CHRL z ASEAN, jak również z niektórymi państwami

$28 \mathrm{~W}$ zakresie wymiany handlowej, przed kryzysem finansowym 2008 roku, ponad jej połowa miała charakter regionalny w Azji. Chińska wymiana handlowa w pierwszej dekadzie XXI wieku rosła znacznie szybciej niż amerykańska. W 2004 roku Chiny stały się największym partnerem handlowym Japonii i Korei Południowej, w 2007 roku - Australii. Warto też zauważyć, że w wymianie handlowej między Chinami a Azją nie ma tak dużych dysproporcji między importem a eksportem jak np. w odniesieniu do USA czy UE. Chiny zaczynają więc być postrzegane jako gospodarczy lider regionu. K. Dumbaugh, China's Foreign Policy and 'Soft Power' in South America, Asia and Africa, Congressional Research Service, Washington 2008, s. 91-97.

29 Znaczącym ograniczeniem możliwości międzynarodowego zaangażowania Chin są również możliwości i umiejętności wykorzystania posiadanych zasobów na arenie międzynarodowej. Kluczowe w tym zakresie pytanie brzmi: Czy ChRL posiada wystarczająco dużo zasobów, by móc podejmować aktywną rolę choćby w samej tylko Azji? Dobrym przykładem jest pomoc humanitarna udzielona przez Chiny ofiarom azjatyckiego tsunami w 2005 roku. Chociaż była to największa suma ( $83 \mathrm{mln}$ dol.), jaką Chiny kiedykolwiek przeznaczyły na taki cel, pozostawała bez wrażenia w porównaniu z wielusetmilionowymi wydatkami USA, Australii czy Japonii na ten sam cel. Jednocześnie, mimo mniejszych odległości geograficznych, logistycznie pozostawały daleko w tyle za np. USA w zakresie możliwości jej udzielenia.

30 Z. Zhu, China's New Diplomacy: Rationale, Strategies and Significance, Ashgate, Burlington 2010, s. $42-43$.

31 A. Liebman, Trickle-Down Hegemony? China's 'Peaceful Rise' and Dam Building on Mekong, „Contemporary Southeast Asia” 2005 Vol. 27, Nr 2, s. 281-304; J.I. Dominiguez, China’s Relations with Latin America: Shared Gains, Asymmetric Hopes, Inter-American Dialogue, Washington 2006. 
afrykańskimi. ${ }^{32}$ Nie bez znaczenia jest coraz częstsze postrzeganie polityki gospodarczej Chin za granicą, zwłaszcza w państwach rozwijających się, jako przejawu gospodarczego neokolonializmu petryfikującego sytuację ekonomiczną, społeczną i polityczną w krajach będących obiektami chińskich inwestycji. Coraz częściej pojawia się resentyment wobec chińskich przedsiębiorstw nieangażujących w projekty miejscowej ludności, preferując sprowadzanie pracowników z Chin. ${ }^{33}$ Naraża to na szwank wizerunek Chin jako „bratniego” państwa rozwijającego się, pragnącego być pomostem do świata państw rozwiniętych. Wątpliwości jest więc wiele. Można jednak zaryzykować tezę, że jeśli ChRL nadal chce korzystać z potencjału, jaki drzemie w systemie międzynarodowym, to w jej własnym interesie będzie przyjęcie na siebie większej odpowiedzialności za jego kształt.

\section{Prognoza}

Jak w każdym opracowaniu dotyczącym politycznego rozkwitu ChRL również w tym miejscu nie można uciec od pytania, czy i jak Chiny zmienią się w przyszłości, zwłaszcza w kontekście wymienionych czynników ryzyka rysujących się na drodze ich rozwoju. Od zakończenia zimnej wojny Państwo Środka koncentrowało się na stopniowej budowie potęgi gospodarczej, modernizacji społecznej i wojskowej oraz starało się minimalizować zagrożenia zewnętrzne. Wybiegając w przyszłość, rodzi się pytanie, jakimi przeobrażeniami chińskiej polityki międzynarodowej zaowocuje równoległy rozwój wewnętrzny i rosnąca siła na arenie światowej.

$\mathrm{W}$ perspektywie najbliższych dwudziestu lat zmiana kierunku rozwoju Chin wydaje się mało prawdopodobna. Musiałaby ona być związana z gwałtowną zmianą w linii sukcesji w KPCh, kryzysem wewnętrznym lub gwałtownymi i nieprzewidywalnymi wydarzeniami międzynarodowymi, przykładowo poważnym konfliktem zbrojnym. Potencjał chiński rozwija się sukcesywnie, a ograniczenia wewnętrzne i zewnętrzne jego wzrostu pozostają stałe. Chinom byłoby bardzo trudno utrzymać dotychczasowe tempo rozwoju i utrzymać spokój wewnętrzny, jednocześnie angażując się w zmianę międzynarodową na dużą skalę. Zarazem odejście od pokojowej wizji stosunków międzynarodowych naraziłoby ChRL na eksplozję już nabrzmiałych resentymentów regionalnych w Azji Południowo-Wschodniej. Zmienną, jaką jest międzynarodowy awans ChRL, należy również postrzegać w kontekście innych

\footnotetext{
32 Z. Zhu, op.cit., s. 52-53, 193-195.

33 J.I. Dominiguez, op.cit.
} 
zmiennych - awansu Indii, sytuacji Japonii czy Federacji Rosyjskiej. Wiele wskazuje na to, że obecna droga polityczna Chin jest już wystarczająco złożona sama w sobie, by kierownictwo Państwa Środka ryzykowało jej dalszą komplikację gwałtownymi ruchami międzynarodowymi. Jednocześnie jest na tyle obiecująca, że jej porzucenie wydaje się mało prawdopodobne. Nie wyklucza to jednak sporów wewnętrznych w samych Chinach co do sposobu zmierzania do celu.

Zarówno siłą napędową, jak i głównym ograniczeniem polityki zagranicznej Państwa Środka pozostaje sytuacja wewnętrzna Chin. Wiele wskazuje na to, że przywództwo KPCh przeanalizowało historyczne przypadki porażek budowy pozycji mocarstwowej przez wiele innych mocarstw w przeszłości. $Z$ tego powodu politycy chińscy będą unikać konfrontacji z mocarstwem dominującym - Stanami Zjednoczonymi, starać się nie polegać wyłącznie na własnej potędze militarnej oraz budować pozytywny wizerunek międzynarodowy państwa. Wygląda na to, że są świadomi, iż potrzebują do tego czasu i relatywnie spokojnej sytuacji międzynarodowej. ${ }^{34}$ Zmiany w zachowaniach międzynarodowych Chin będą wynikać nie tylko ze zmiany ich pozycji, ale również z ewolucji samego ładu międzynarodowego, ciążącego coraz bardziej ku wielobiegunowości oraz przesuwającego swe centrum gospodarczo-polityczne w kierunku Azji. To w wyniku tych globalnych procesów Chiny mogą zyskać najwięcej.

\section{Risk Factors in Contemporary China International Policy}

China's Power seems to be beyond discussion. People's Republic of China (PRC) is the fourth biggest state in the world and its population accounts for one sixth of the human race. The Middle Kingdom's economy is booming, its international status rises, its middle class is growing. All these features prove that PRC has a great political and economic potential. However, the future of China is not yet certain. Political elites of the state will have to face a series of challenges, concerning demography, coexistence of communist state with market economy, rising competition on energy markets, etc. Identifying these potential threats for PRC's future development is crucial both for the Middle Kingdom in regards to its internal and international politics, and for foreign Powers in regards to their future agenda concerning relations with China.

${ }^{34}$ J. Mearshimer, op.cit. 


\section{Les facteurs de risque dans la politique internationale de la Chine contemporaine}

Après la première décennie du XXIe siècle, la puissance de la Chine semble être évidente. La République Populaire de Chine est le quatrième pays au monde en termes de territoire avec une population comprenant un sixième du globe. L'économie chinoise est en plein essor, le statut international du pays augmente, la classe moyenne est de plus en plus nombreuse. Le fait que l'Empire du Milieu a maintenant un énorme potentiel politique et économique nest pas déterminant pour son avenir. L'élite politique de la Chine devra faire face aux défis de la démographie, de la coexistence du système communiste et de léconomie de marché, de la concurrence accrue dans les marchés de l'énergie dans le monde, etc. La définition des principales menaces pour le futur taux de transformation économique et politique dans l'Empire du Milieu permettra d'identifier les variables pertinentes pour la formulation de prévisions pour la politique nationale et internationale de la Chine contemporaine. 